\title{
Revision of the elusive ant genus Rhopalomastix (Hymenoptera, Formicidae, Myrmicinae) in Thailand based on morphology and DNA barcodes, with descriptions of three new species - Corrigendum
}

\author{
Wendy Y. WANG ${ }^{1, *}$, Gordon W.J. YONG ${ }^{2}$ \& Weeyawat JAITRONG ${ }^{3}$ \\ ${ }^{1}$ Lee Kong Chian Natural History Museum, National University of Singapore, \\ 2 Conservatory Drive, Singapore 117377. \\ ${ }^{2}$ Department of Biological Sciences, Faculty of Science, National University of Singapore, \\ 16 Science Drive 4, Singapore 117558. \\ ${ }^{3}$ Natural History Museum, National Science Museum, Technopolis, Khlong 5, \\ Khlong Luang, Pathum Thani, 12120 Thailand. \\ *Corresponding author: nhmwyw@nus.edu.sg - wywang24@gmail.com \\ ${ }^{2}$ Email: gordonyongwj@gmail.com \\ ${ }^{3}$ Email: polyrhachis@yahoo.com \\ ${ }^{1}$ urn:1sid:zoobank.org:author:41730B76-D515-42D0-A3BE-2788ADFDAA8A \\ ${ }^{2}$ urn:lsid:zoobank.org:author:3D3752DF-3522-4DEE-B4A3-7E85CA774263 \\ ${ }^{3}$ urn:1sid:zoobank.org:author:E456F06F-486F-4BD5-AEE6-6DCA639C3E27 \\ $1 \odot$ https://orcid.org/0000-0003-0745-4702 \\ ${ }^{3} \odot$ https://orcid.org/0000-0003-1362-0754
}

Wang W.Y., Yong G.W.J. \& Jaitrong W. 2021. Revision of the elusive ant genus Rhopalomastix (Hymenoptera, Formicidae, Myrmicinae) in Thailand based on morphology and DNA barcodes, with descriptions of three new species - Corrigendum. European Journal of Taxonomy 746: 186-187. https://doi.org/10.5852/ejt.2021.746.1329

The present corrigendum corrects errors that occurred in Wang et al. (2021).

Page 117, citation: the year of publication should be 2021 instead of 2012:

Wang W.Y., Yong G.W.J. \& Jaitrong W. 2012. Revision of the elusive ant genus Rhopalomastix (Hymenoptera, Formicidae, Myrmicinae) in Thailand based on morphology and DNA barcodes, with descriptions of three new species. European Journal of Taxonomy 739: 117-157.

Should read:

Wang W.Y., Yong G.W.J. \& Jaitrong W. 2021. Revision of the elusive ant genus Rhopalomastix (Hymenoptera, Formicidae, Myrmicinae) in Thailand based on morphology and DNA barcodes, with descriptions of three new species. European Journal of Taxonomy 739: 117-157. 


\section{Page 128, Distribution:}

Thailand (central, Nakhon Nayok Province) (Fig. 16a).

Should read:

Thailand (northeast, Sakhon Nakhon Province) (Fig. 16a).

\section{Reference}

Wang W.Y., Yong G.W.J. \& Jaitrong W. 2021. Revision of the elusive ant genus Rhopalomastix (Hymenoptera, Formicidae, Myrmicinae) in Thailand based on morphology and DNA barcodes, with descriptions of three new species. European Journal of Taxonomy 739: 117-157.

https://doi.org/10.5852/ejt.2021.739.1271

Published on: 27 April 2021

Printed versions of all papers are also deposited in the libraries of the institutes that are members of the EJT consortium: Muséum national d'histoire naturelle, Paris, France; Meise Botanic Garden, Belgium; Royal Museum for Central Africa, Tervuren, Belgium; Royal Belgian Institute of Natural Sciences, Brussels, Belgium; Natural History Museum of Denmark, Copenhagen, Denmark; Naturalis Biodiversity Center, Leiden, the Netherlands; Museo Nacional de Ciencias Naturales-CSIC, Madrid, Spain; Real Jardín Botánico de Madrid CSIC, Spain; Zoological Research Museum Alexander Koenig, Bonn, Germany; National Museum, Prague, Czech Republic. 